\title{
Screening of Different Non Systemic and Systemic Fungicides for the Wilt Disease of Cotton under in vitro Condition of South Gujarat
}

\author{
Bhavik K. Patel ${ }^{\text {* }}$, Prashant B. Sandipan ${ }^{1}$, R. K. Patel ${ }^{2}$ and S. K. Chawada ${ }^{2}$ \\ ${ }^{1}$ Main Cotton Research Station (MCRS), ${ }^{2}$ Krushi Vigyan Kendra, Navsari Agricultural \\ University (NAU), Surat, (Gujarat), India \\ *Corresponding author
}

\begin{abstract}
A B S T R A C T
In this experiment, different districts of South Gujarat were closely examined for the presence of wilt disease in different cultivars/ Bt hybrids during the crop season to know the current scenario of wilt disease. The respective FOV wilt pathogen was purified, identified and isolated from the infected cotton plant. Here, different fungicides were tested for their effect on the growth of Fusarium oxysporum f. sp. vasinfectum (FOV) using poisoned food technique. The technique involves cultivation of test organism on a medium containing the test chemical. In all the experiments, PDA was used as basal medium. Fungicides viz., six non systemic and six systemic fungicides were evaluated at three different concentrations by poisoned food technique for evaluating their efficacy against Fusarium oxysporum f. sp. vasinfectum. Among them, non systemic fungicides copper oxychloride and systemic fungicides carbendazim significantly inhibited the growth of the Fusarium oxysporum f. sp. vasinfectum and proved strongly fungitoxic in nature against the FOV pathogen.
\end{abstract}

\begin{tabular}{|l|}
\hline Ke y w or d s \\
Cotton, Wilt, \\
Disease, Fungicide
\end{tabular}

\section{Introduction}

Cotton (Gossypium spp.) is one of the most important fiber crops playing a key role in economic and social scenario of the globe. It is oldest among the commercial crops of the world providing fiber for clothing of the mankind. It is also known as "THE WHITE GOLD" or "THE KING OF FIBERS". Cotton is an important fiber yielding crop of global importance, which is grown in tropical and subtropical regions of more than 80 countries of the world. The major cotton producing countries are USA, China, India, Pakistan,
Uzbekistan, Egypt, Argentina, Australia, Greece, Brazil and Turkey. In total global cotton production 70 per cent cotton production comes from the four countries, which includes China (27\%), India (22\%), USA $(13 \%)$ and Pakistan $(8 \%)$. For many developing and underdeveloped countries cotton export is the main source of foreign exchange earnings. The cotton crop is affected by plenteous pests, diseases and weeds etc causing solemn economic losses in a crop. In the post Bt cotton era (2002 onwards) sucking pests like Aphids, Jassids, Thrips, Whitefly, Mealybugs, Myrid bugs and 
Mites continue to ravage the cotton crop and pose a serious threat to sustain and enhance cotton productivity (Tanweer, 2013). The wilt disease is responsible for serious losses to the crop in the central and western India on a large scale and on almost all the cultivated varieties of both $G$. arboreum and $G$. herbaceum, the two indigenous species, especially in black cotton soils of Maharashtra, Madhya Pradesh, Karnataka and Gujarat. At present the most of cultivated cultivars are susceptible to wilt disease (Fusarium oxysporum f. sp. vasinfectum) and caused 54-60\% yield loss (Anon., 2003) because of reduced stand, stunted growth, small bolls and poor lint quality. The symptoms of Fusarium oxysporum f. sp. vasinfectum is both seed borne and soil borne and colonizes the roots and vascular system of susceptible cotton cultivars, causing root and vascular discoloration, wilting and sometimes death of the plant (Chen et al., 1985, Hillocks, 1992 and Davis et al., 1996). Looking to the frequent occurrence in one or other region and inflicting serious damage under South Gujarat region. Hence, the present investigation was undertaken to clarify deeply and thoroughly the wilt disease in these districts.

\section{Materials and Methods}

Different fungicides were tested for their effect on the growth of Fusarium oxysporum f. sp. vasinfectum using poisoned food technique (Sinclair and Dhingra, 1985). The technique involves cultivation of test organism on a medium containing the test chemical. In all the experiments, Potato Dextrose Agar (PDA) was used as basal medium. The required quantity of each chemical as shown in the Discussion part was incorporated aseptically in $100 \mathrm{ml}$ of PDA in $250 \mathrm{ml}$ flasks at the time of pouring the media in Petri plates. The medium shaken well to give uniform dispersal of the chemical and then in each Petri plates $20 \mathrm{ml}$ of medium will be poured aseptically and allowed to solidify. The Petri plates were inoculated with $5 \mathrm{~mm}$ diameter mycelial disc, cut from the periphery of seven days old fungus cultures. The mycelial disc was placed in the center of the plates in an inverted portion to make a direct contact with the poisoned medium and incubated at $27 \pm 2^{\circ} \mathrm{C}$ for 10 days after inoculation. Simultaneously a suitable control was also maintained by growing the fungus on chemical free PDA. Observations on linear growth were recorded when full growth of fungus observed in control Petri plate.

The per cent growth inhibition (PGI) of the fungus in each treatment was calculated by using following formula given by Vincent (1947).

PGI $=\frac{100(\text { DC-DT) }}{\text { DC }}$

Where,

PGI $=$ Per cent growth inhibition

$\mathrm{DC}=$ Average diameter of mycelial colony in control set (mm)

DT $=$ Average diameter of mycelial colony of treated set $(\mathrm{mm})$

\section{Results and Discussion}

\section{Effect of different non systemic fungicides} on growth inhibition of Fusarium oxysporum f. sp. vasinfectum

The non systemic fungicides viz., thiram (75 WP), mancozeb (75WP), zineb (75WP), chlorothalonil (75 WP), copper oxychloride (50 WP), and captan (50WP) were evaluated at 1500,2000 and $3000 \mathrm{ppm}$ concentrations using poisoned food technique. The results revealed that as fungicidal concentration increases, the growth of pathogen decreased. The observations regarding per cent inhibition of linear growth are presented in Table 1 and 
depicted in Plate 1. Out of six non systemic fungicides tested, efficacy of copper oxychloride was considered the best with highest mean per cent growth inhibition of pathogen $81.77,86.83$ and 88.37 at 1500 , 2000 and 300ppm concentration respectively.

The next best fungicides in order of merit at $3000 \mathrm{ppm}$ concentration was thiram $(79.84 \%)$ which, was followed by chlorothalonil (77.52\%), mancozeb (63.17\%), zineb $(60.46 \%)$ and captan $(48.83 \%)$. While, it is followed in order of merit at $2000 \mathrm{ppm}$ concentration was chlorothalonil $(76.74 \%)$ followed by thiram (75.19\%), mancozeb $(61.62 \%)$, zineb $(55.43 \%)$ and captan (43.80\%) and at $1500 \mathrm{ppm}$ concentration was thiram $(74.41 \%)$ followed by chlorothalonil (73.25\%), zineb (51.94\%), mancozeb (51.54\%) and captan (31.77\%) inhibiting the growth of pathogen Fusarium oxysporum $\mathrm{f}$. sp. vasinfectum.

It is evident from the results that the growth inhibition of Fusarium oxysporum f. sp. vasinfectum increased as increase in the concentration of the respective chemicals.

Table.1 Inhibitory effect of non-systemic fungicides against pathogen under in vitro test

\begin{tabular}{|c|c|c|c|c|}
\hline Sr. No. & $\begin{array}{l}\text { Technical name of } \\
\text { fungicides }\end{array}$ & $\begin{array}{l}\text { Conc. } \\
(\text { ppm })\end{array}$ & $\begin{array}{c}\text { A verage colony } \\
\text { diameter of } \\
\text { pathogen }(\mathrm{mm})\end{array}$ & $\begin{array}{c}\text { Per cent } \\
\text { inhibition over } \\
\text { control }\end{array}$ \\
\hline $\mathbf{T}_{1}$ & Thiram & $\begin{array}{l}1500 \\
2000 \\
3000\end{array}$ & $\begin{array}{c}4.74^{*}(22.00)^{* *} \\
4.67(21.33) \\
4.22(17.33)\end{array}$ & $\begin{array}{r}74.41 \\
75.19 \\
79.84\end{array}$ \\
\hline $\mathbf{T}_{2}$ & Mancozeb & $\begin{array}{l}1500 \\
2000 \\
3000\end{array}$ & $\begin{array}{l}6.49(41.67) \\
5.79(33.00) \\
5.67(31.67)\end{array}$ & $\begin{array}{l}51.54 \\
61.62 \\
63.17\end{array}$ \\
\hline $\mathbf{T}_{3}$ & Zineb & $\begin{array}{l}1500 \\
2000 \\
3000\end{array}$ & $\begin{array}{l}6.47(41.33) \\
6.23(38.33) \\
5.87(34.00)\end{array}$ & $\begin{array}{l}51.94 \\
55.43 \\
60.46\end{array}$ \\
\hline $\mathbf{T}_{4}$ & Chlorothalonil & $\begin{array}{l}1500 \\
2000 \\
3000\end{array}$ & $\begin{array}{l}4.84(23.00) \\
4.53(20.00) \\
4.45(19.33)\end{array}$ & $\begin{array}{l}73.25 \\
76.74 \\
77.52\end{array}$ \\
\hline $\mathbf{T}_{5}$ & Copper oxychloride & $\begin{array}{l}1500 \\
2000 \\
3000\end{array}$ & $\begin{array}{l}4.02(15.67) \\
3.48(11.67) \\
3.24(10.00)\end{array}$ & $\begin{array}{l}81.77 \\
86.83 \\
88.37\end{array}$ \\
\hline $\mathbf{T}_{6}$ & Captan & $\begin{array}{l}1500 \\
2000 \\
3000\end{array}$ & $\begin{array}{l}7.69(58.67) \\
6.99(48.33) \\
6.67(44.00)\end{array}$ & $\begin{array}{l}31.77 \\
43.80 \\
48.83\end{array}$ \\
\hline $\mathbf{T}_{7}$ & Control & - & $9.30(86.00)$ & - \\
\hline & S. Em. \pm & & 0.08 & \\
\hline & $\mathrm{CD}$ at $5 \%$ & & 0.23 & \\
\hline & $\mathrm{CV} \%$ & & 2.49 & \\
\hline
\end{tabular}

*Figures outside the parentheses indicate $\sqrt{\mathrm{x}}+0.5$ transformation value

**Figures in parentheses indicate original values 
Table.2 Inhibitory effect of systemic fungicides against pathogen under in vitro test

\begin{tabular}{|c|c|c|c|c|}
\hline $\begin{array}{l}\text { Sr. } \\
\text { No. }\end{array}$ & Technical name of fungicides & $\begin{array}{l}\text { Conc. } \\
\text { (ppm) }\end{array}$ & $\begin{array}{l}\text { Average colony } \\
\text { diameter of } \\
\text { pathogen }(\mathbf{m m})\end{array}$ & $\begin{array}{l}\text { Per cent inhibition } \\
\text { over control }\end{array}$ \\
\hline $\mathbf{T}_{1}$ & Carbendazim & $\begin{array}{l}100 \\
250 \\
500\end{array}$ & $\begin{array}{c}2.72^{*}(7.00)^{* *} \\
0.71(0.00) \\
0.71(0.00)\end{array}$ & $\begin{array}{c}91.86 \\
100.00 \\
100.00\end{array}$ \\
\hline $\mathbf{T}_{2}$ & Fosetyl AL & $\begin{array}{l}100 \\
250 \\
500\end{array}$ & $\begin{array}{l}7.11(50.00) \\
6.52(42.00) \\
4.30(18.00)\end{array}$ & $\begin{array}{l}41.86 \\
51.16 \\
79.06\end{array}$ \\
\hline $\mathbf{T}_{3}$ & Thiophanate methyl & $\begin{array}{l}100 \\
250 \\
500\end{array}$ & $\begin{array}{l}4.56(20.33) \\
4.30(18.00) \\
4.26(17.67)\end{array}$ & $\begin{array}{l}76.36 \\
79.06 \\
79.45\end{array}$ \\
\hline $\mathbf{T}_{4}$ & Carboxin & $\begin{array}{l}100 \\
250 \\
500\end{array}$ & $\begin{array}{c}3.67(13.00) \\
3.13(9.33) \\
3.08(9.00)\end{array}$ & $\begin{array}{l}84.88 \\
89.15 \\
89.53\end{array}$ \\
\hline $\mathbf{T}_{5}$ & Propiconazole & $\begin{array}{l}100 \\
250 \\
500\end{array}$ & $\begin{array}{l}3.08(9.00) \\
2.79(7.33) \\
0.71(0.00)\end{array}$ & $\begin{array}{c}89.53 \\
91.47 \\
100.00\end{array}$ \\
\hline $\mathbf{T}_{6}$ & Azoxystrobin & $\begin{array}{l}100 \\
250 \\
500\end{array}$ & $\begin{array}{l}4.95(24.00) \\
4.92(23.67) \\
4.53(20.00)\end{array}$ & $\begin{array}{l}72.09 \\
72.47 \\
76.74\end{array}$ \\
\hline $\mathbf{T}_{7}$ & Control & - & $9.30(86.00)$ & - \\
\hline & S. Em. \pm & & 0.09 & \\
\hline & $\mathrm{CD}$ at $5 \%$ & & 0.25 & \\
\hline & $\mathrm{CV} \%$ & & 3.88 & \\
\hline
\end{tabular}

*Figures outside the parentheses indicate $\sqrt{\mathrm{x}}+0.5$ transformation value

**Figures in parentheses indicate original values

Plate.1

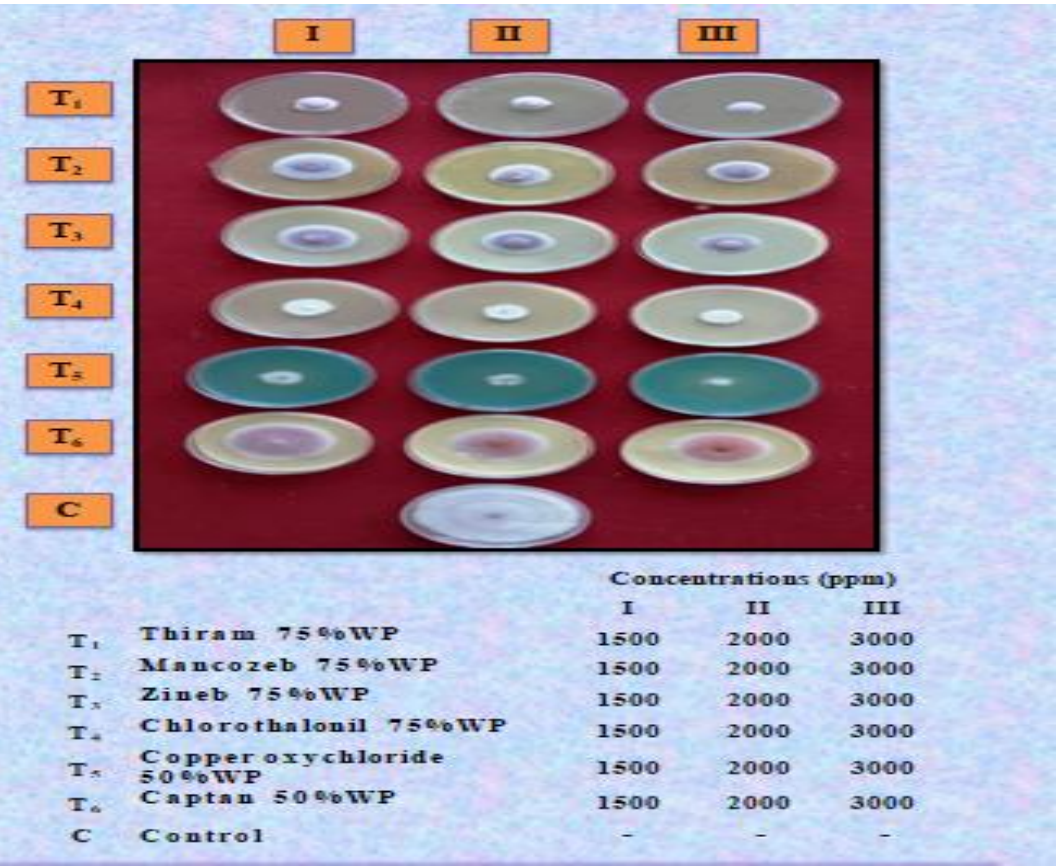




\section{Plate.2}

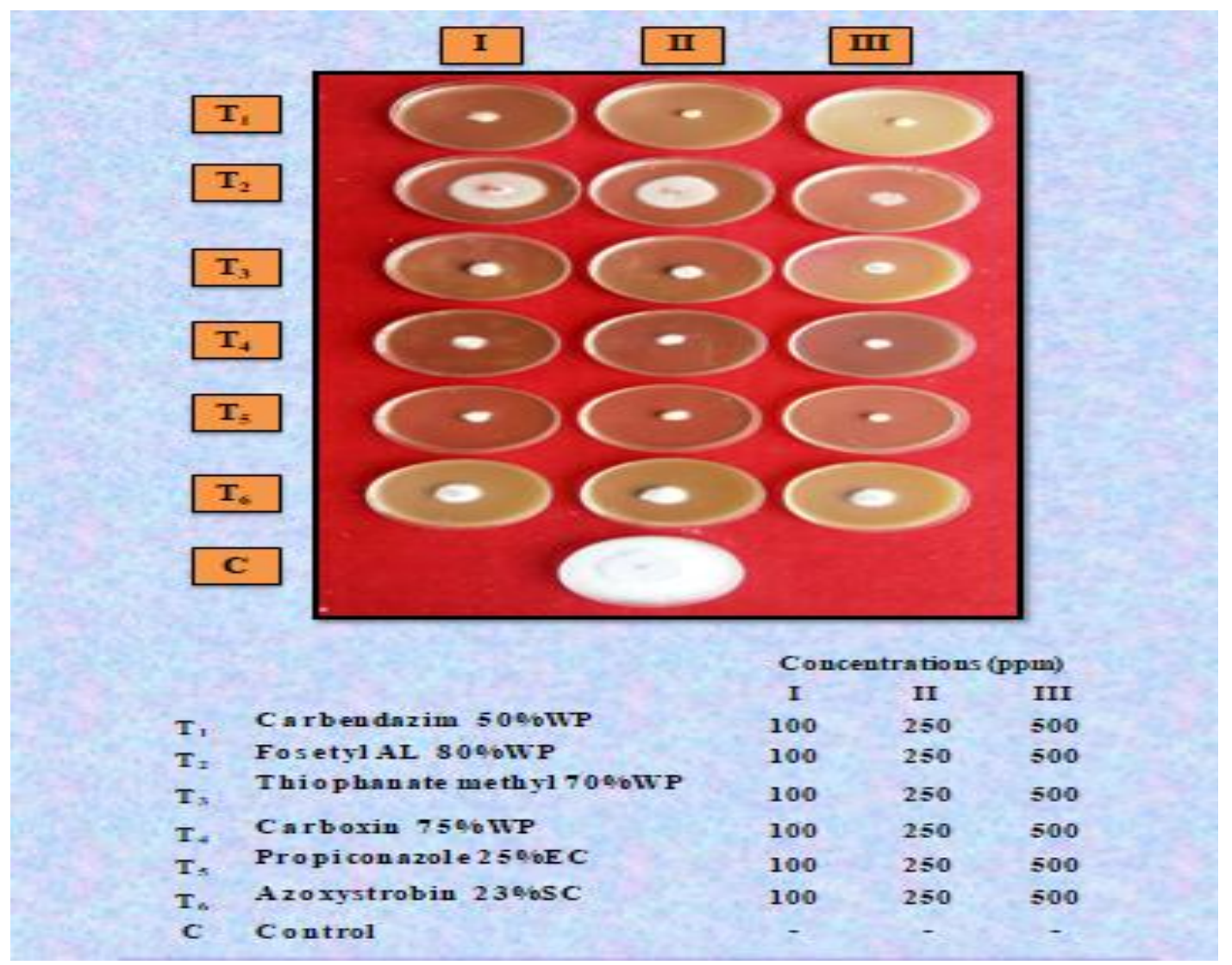

Effect of different systemic fungicides on growth inhibition of Fusarium oxysporum $f$. sp. vasinfectum

The systemic fungicides viz. Carbendazim (50 WP), Fosetyl AL (80 WP), Thiophanate methyl (70 WP), Carboxin (75WP), Propiconazole (25EC) and Azoxystrobin (23SC) were evaluated at 100, 250 and $500 \mathrm{ppm}$ concentrations. The observations regarding per cent inhibition of linear growth are presented in Table 2 and depicted in the Plate 2. All the six different systemic fungicides screened at three concentrations viz., 100, 250 and 500ppm were found significantly superior in inhibiting the mycelial growth of Fusarium oxysporum f. sp. vasinfectum. Out of six systemic fungicides, carbendazim at 250 and 500ppm and propiconazole at 500ppm concentration inhibited cent per cent growth of the Fusarium oxysporum f. sp. vasinfectum.

The next best fungicide in order of merit at 500ppm concentration was carboxin $(89.53 \%)$ followed by thiophanate methyl (79.45), fosetyl AL (79.06\%) and azoxystrobin $(76.74 \%)$. While, in case of the next best treatment at $250 \mathrm{ppm}$ concentration was propiconazole (91.47\%) followed by carboxin (89.15\%), thiophanate methyl (79.06\%), azoxystrobin (72.47\%) and fosetyl AL $(51.16 \%)$ and at $100 \mathrm{ppm}$ concentration was carbendazim $(91.86 \%)$ followed by propiconazole $(89.53 \%)$, carboxin $(84.88 \%)$, thiophanate methyl (76.36\%), azoxystrobin (72.09\%) and fosetyl AL (41.86\%) respectively. 
It is evident from the results that the growth inhibition of Fusarium oxysporum f. sp. vasinfectum increased as increase in the concentration of the chemicals. The fungicide, carbendazim and propiconazole were proved to be the most effective fungicide.

\section{Acknowledgement}

Author is highly thankful to Main Cotton Research Station (MCRS), NAU, Surat (Gujarat) and Department of Plant Pathology, N. M. College of Agriculture, NAU, Navsari for providing the required facility and other necessary arrangements for conducting the experiment in an efficient way. This research paper is a part of M.Sc. thesis submitted to Navsari Agricultural University (NAU), Navsari (Gujarat).

\section{References}

Anonymous (2003). Assessment of the impact and main dynamics of cotton diseases affecting in particular small-scale production systems in SouthernAfrica, https://www.icac.org/ projects/ commonfund/seacf_disease/proj11fin al.pdf. Accessed on 18 June 2017.
Chen, Q., Ji, X. and Sun, W. (1985). Identification of races of cotton wilt Fusarium in China. Journal of Agricultural Sciences, 6: 1-6.

Davis, R. D., Moore, N. Y. and Kochman, J. K. (1996). Characterization of a population of Fusarium oxysporum $\mathrm{f}$. sp. vasinfectum causing wilt of cotton in Australia. Australian Journal of Agricultural Research. 47: 11431156.

Hillocks, R. J. (1992). Fusarium wilt. In: Hillocks, R. J. (Ed.) Cotton diseases. Melksham UK. Redwood Press Ltd. Pp.127-160.

Sinclair, J. B. and Dhingara, O. D. (1985). "Basic Plant Pathology Methods." Publ. by CRC Press. Inc. Corporate Buld, M.W. Boca Raton, Florida. Pp. 285-315.

Tanweer, Asif. 2013. Pesticides in Cotton The Road Ahead. National convention on India cotton: Gearing up for Global leadership. Pp. 9-11.

Vincent, J. M. (1947) Distortion of fungal hyphae in presence of certain inhibitors. Pp. 159-850.

\section{How to cite this article:}

Bhavik K. Patel, Prashant B. Sandipan, R. K. Patel and Chawada, S. K. 2020. Screening of Different Non Systemic and Systemic Fungicides for the Wilt Disease of Cotton under in vitro Condition of South Gujarat. Int.J.Curr.Microbiol.App.Sci. 9(12): 820-825. doi: https://doi.org/10.20546/ijcmas.2020.912.098 